\title{
REVIEW
}

\section{Stable carbon isotopes in seagrasses: variability in ratios and use in ecological studies}

\author{
M. A. Hemminga*, M. A. Mateo \\ Netherlands Institute of Ecology, Centre for Estuarine and Coastal Ecology, Vierstraat 28, 4401 EA Yerseke, The Netherlands
}

\begin{abstract}
Seagrass $\delta^{1} \mathrm{C}$ values reported in the literature show variation over a range of approximately $20 \%$. A frequency histogram constructed on the basis of the collected data set shows a unimodal distribution, with values between -10 and $-11 \%$ (relative to the PDB standard) found with the highest frequency. Seagrasses thus have stable carbon isotope signatures which are typically less depleted in ${ }^{13} \mathrm{C}$ than those of other groups of aquatic primary producers. This points to a characteristic set of physiological, anatomical and perhaps environmental features shared by all seagrasses. A significant negative correlation exists between seagrass $\delta^{13} \mathrm{C}$ values and geographical latitude of the sampling location, indicating that from tropical to temperate regions seagrasses tond to become more ${ }^{13} \mathrm{C}$ depleted. The physiological and environmental causes of variability are discussed. The most relevant environmental factors inducing variation in seagrass $\delta^{13} \mathrm{C}$ values appear to be, in order of decreasing importance, source carbon, irradiance and temperature. The integrated information reflected in the natural $\delta^{13} \mathrm{C}$ values of seagrasses can be used in support of the reconstruction of environmentally related growth dynamics on the scale of individual shoots and that of entire populations. In addition, ${ }^{13} \mathrm{C}$ may be used experimentally as a tracer of carbon flow in short term carbon allocation and production studies.
\end{abstract}

KEY WORDS: Stable carbon isotopes · Seagrasses · Isotope signatures · Variability

\section{INTRODUCTION}

Seagrasses are the only descendants of terrestrial angiosperms which have been able to invade the marine environment (Den Hartog 1970, Dring 1982). They can be found in marine shallow waters all over the world at tropical and temperate latitudes; the geographical distribution of some species even extending to polar areas (Den Hartog 1970, Kuo \& McComb 1989). In recent decades, scientific attention to these plants has strongly increased, coinciding with the growing awareness that seagrass meadows may have conspicuous impacts on the stability and morphogene. sis of the coastal zone (e.g. Scoffin 1970, Harlin et al. 1982, Hemminga \& Nieuwenhuize 1990), and that they

·E-mail; hemminga@cemo.nioo.knaw.nl fulfill important ecological roles in the coastal environment, such as in providing food and shelter to many organisms (Bell \& Pollard 1989. Howard et al. 1989, Heck et al. 1995). However, there is still a considerable deficit in knowledge on the functioning of these plants in comparison to terrestrial and freshwater plants.

It has become apparent that the analysis of the stable carbon isotope composition of plants is a useful tool in understanding physiological processes and the response of plants to varying environmental conditions. In addition, studies of the natural abundance of stable carbon isotopes in plants and in organisms at higher trophic levels has contributed to the understanding of the food web in various ecosystems (Peterson \& Fry 1987, Farquhar et al. 1989, Ehleringer \& Osmond 1989. Raven 1992, Lajtha \& Marshall 1994). The above, however, so far hardly pertains to seagrasses. There is a substantial (and growing) body of data on stable car- 
bon isotope signatures in seagrasses, but the data are scattered over studies carried out with different purposes. At the current state-of-the-art, usually only a beginning of an ecological interpretation has been possible.

In this paper we review the presently available literature data on stable carbon isotope ratios in seagrasses, with particular emphasis on the factors relevant for the observed variation of isotope signatures. Subsequently, we address the potential of stable carbon isotopes for studies of seagrass ecology.

Throughout the paper we will use the familiar $\delta$ notation whenever isotopic compositions are given, which indicates the deviation (\%) of the isotopic composition of the sample from a standard. In this review all $\delta$ values given are relative to the limestone PeeDee Belemnite (PDB) standard. We are aware of the fact that the International Union of Pure and Applied Chemistry (IUPAC) recently has recommended the reporting of carbon isotopic ratios relative to Vienna PeeDee Belemnite (V-PDB) (IUPAC 1994, Limnology \& Oceanography 1995). However, as the data we review in the present paper all were given relative to the PDB standard, we have opted to discuss the data relative to the same standard.

\section{VARIABILITY}

The range of natural $\delta^{13} \mathrm{C}$ values in seagrasses is substantial, as has been evident since McMillan et al. (1980) published their paper on isotopic variability in seagrasses. Table 1 gives an overview of the natural variation in $\delta^{13} \mathrm{C}$ values which has been reported up to now, derived from 31 studies carried out worldwide. The values were determined in 48 different species, i.e. nearly all seagrass species are present in the data set. The extremes of the range, i.e. a value of $-3.0 \%$ reported for Syringodium filiforme at the high end of the scale, and a value of $-23.8 \%$ for Halophila beccarii at the low end, have not changed since McMillan et al. (1980) published their study, but many data falling within this range have been reported since then

The data set forming the basis of Table 1 was used to construct a frequency histogram of $\delta^{1.3} \mathrm{C}$ values (Fig. 1). The data are not clustered in distinct groups but show a unimodal distribution; values between -10.0 and $-11.0 \%$ are found with the highest frequency. Even the most negative values show an only comparatively limited depletion of the ${ }^{13} \mathrm{C}$ isotope compared to other aquatic primary producers, i.e. freshwater macrophytes (values extending to $-50 \%$; Keeley \& Sandquist 1992), marine macroalgae (values extending to $-34 \%$; Fischer \& Wiencke 1989, Raven et al. 1995), and plank- frequencies delta-13C values

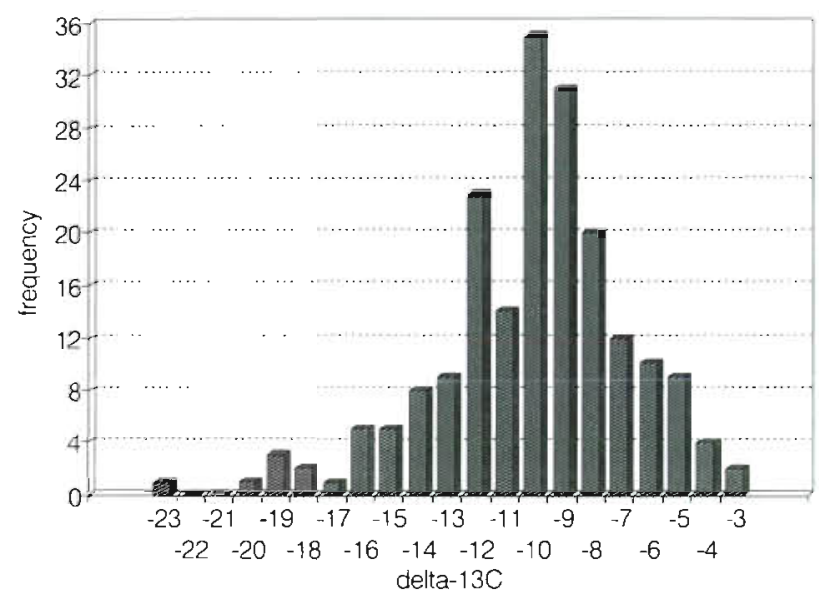

Fig. 1 Frequency hislogram of seagrass $\delta^{13} \mathrm{C}$ values as reported in the literature. The data in the figure are taken from the references indicated in Table 1

tonic freshwater and marine algae (minimum values of approximately -46 and $-32 \%$, respectively; France 1995).

An interesting picture also emerges when the relation between seagrass $\delta^{13} \mathrm{C}$ values and the corresponding geographical latitude of the sampling sites is considered. A moderate, but significant, negative correlation exists $(p<0.001)$ between $\delta^{13} \mathrm{C}$ values and sampling latitudes (Fig 2), indicating that from tropical

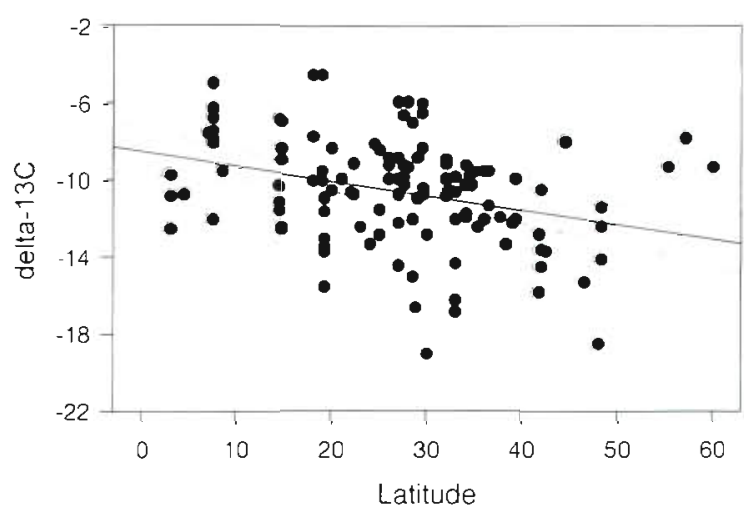

Fig. 2. Relation between seagrass $\delta^{13} \mathrm{C}$ values and geographical latitude. Data are taken from the references mentıoned in Table 1. The fitted line $(r=-0.32, p<0.001)$ is described by the equation: $\delta^{13} \mathrm{C}=-8.532-0.0749$ latitude. Dotted lines indicate $95 \%$ confidence intervals. If several observations on a species were made at the same location, the average value is used. Observations that were influenced by the proximity of mangroves (ff explicitly stated), were not included Latitudes corresponding to the reported $\delta^{13} \mathrm{C}$ value were either obtained directly from the publications, or taken from geographical maps 
Table 1 . Seagrass $\delta^{13} \mathrm{C}$ variability. The list of $104 \delta^{13} \mathrm{C}$ values for seagrasses given by McMillan et al. (1980) has been updated with 91 new observations. Species have been arranged following den Hartog (1970) as adapted in Kuo \& McComb (1989). 'Values as quoted in McMillan et al. (1980) from various authors. References: 1, Craig (1953); 2, Parker (1964); 3, Smith \& Epstein (1971); 4. Smith et al. (1976); 5, Black \& Bender (1976); 6. Benedict \& Scott (1976); 7, Parker (1976); 8, Doohan \& Newcomb (1976); 9, Fry (1977); 10, Thayer et al. (1978); 11. MCConnaughey \& MCRoy (1979); 12, Andrews \& Abel (1979); 13, Beer \& Waisel (1979); 14, Fry \& Parker (1979); 15, Beer et al. (1980a); 16, Benedict et al. (1980); 17, McMillan et al. (1980); 18, Fry et al. (1982); (19, Fry et al. (1983); 20, Stephenson et al. (1984); 21, Fry (1984); 22, Zieman et al. (1984); 23, Stephenson et al. (1986); 24, Harrigan et al. (1989); 25, Cooper (1989); 26, Cooper \& DeNiro (1989); 27, Lin et al. (1991); 28, Durako \& Hall (1992); 29, Hemminga et al. (1994); 30, Raven et al. (1995); 31, Yamamuro et al. (1995)

\begin{tabular}{|c|c|c|c|c|c|c|c|c|}
\hline $\begin{array}{l}\text { Family } \\
\text { and genus }\end{array}$ & Spenes & Mean & $\mathrm{n}$ & SD & Min. & Max. & Range & Refs. \\
\hline \multicolumn{9}{|l|}{ Hydrocharitaceae } \\
\hline Enhalus & acoroides (L. f.) Royle & -5.8 & 2 & 1.2 & -6.7 & -4.9 & 1.8 & 17 \\
\hline Thalassia & hemprichil (Ehrenb.) Aschers. & -6.9 & 6 & 1.2 & -8.1 & -5.2 & 2.9 & 17,31 \\
\hline Thalassia & testudinum Banks ex König & -10.9 & 31 & 2.0 & -16.3 & -7.3 & 9.0 & $\begin{array}{l}3,6,7,12,14,15,17 \\
18,22,24,27,28\end{array}$ \\
\hline Halophila & decipiens Ostenfeid & -10.2 & 11 & 1.7 & -13.2 & -7.5 & 5.7 & 12,17 \\
\hline Halophila & ovalis (R. Br.) Hook.f. & -10.0 & 7 & 3.6 & -15.5 & -6.4 & 9.1 & $8,12,17$ \\
\hline Halophila & minor (Zoll.) den Hartog & -8.3 & 2 & 1.3 & -9.2 & -7.4 & 1.8 & 5 \\
\hline Halophila & hawailana Doty \& Stone & -9.1 & 2 & 1.1 & -9.9 & -8.3 & 1.6 & 17 \\
\hline Halophila & stipulaced (Forsk.) Aschers. & -8.7 & 4 & 2.9 & -11.7 & -5.9 & 5.8 & 15,17 \\
\hline Halophila & johnsonii Eiseman & -9.8 & 1 & & & & & 17 \\
\hline Halophila & beccarii Aschers. & -20.4 & 2 & 4.8 & -23.8 & -17.0 & 6.8 & 17 \\
\hline Halophsla & spinulosa (R. Br.) Aschers. & -12.2 & 3 & 28 & -14.5 & -9.1 & 5.4 & 17 \\
\hline Halophila & tricostala Greenway & -20.8 & 1 & & & & & 17 \\
\hline Halophila & engelmanni Aschers. & -12.2 & 4 & 1.5 & -14.7 & -10.9 & 3.8 & $17^{\circ}$ \\
\hline \multicolumn{9}{|l|}{ Posidoniaceae } \\
\hline Posidonia & oceanica (L.) Delile & -11.9 & 3 & 4.1 & -16.4 & -8.3 & 8.1 & 26 \\
\hline Posidonla & angustifolia Cambridge \& Kuo & -9.5 & 2 & 0.4 & -9.8 & -9.2 & 0.6 & 17,30 \\
\hline Posidonia & australis Hook. $f$. & -9.9 & 3 & 1.8 & -11.9 & -11.8 & 0.1 & 17,30 \\
\hline Posidonia & sinuosa Cambridge \& Kuo & -9.9 & 1 & & & & & 17,30 \\
\hline Posidonia & ostenfeldii den Hartog & -12.0 & 1 & & & & & 17 \\
\hline \multicolumn{9}{|l|}{ Cymodoceaceae } \\
\hline Syrngodium & Isoetrfolium (Aschers.) Dandy & -6.0 & 3 & 2.4 & -8.3 & -3.6 & 4.7 & 13,17 \\
\hline Syringodium & fliforme Küz. & -5.9 & 15 & 1.8 & -9.5 & -3.0 & 6.5 & $4,9,14,17^{\circ}, 18,21,22$ \\
\hline Halodule & pinifolid (Miki) den Hartog & -12.0 & 1 & & & & & 17 \\
\hline Halodule & uninervis (Forsk.) Aschers. & -11.2 & 3 & 2.9 & -13.0 & -7.8 & 5.2 & $12,13,17$ \\
\hline Halodule & wrightii Aschers. & -11.5 & 11 & 1.9 & -15.0 & -8.5 & 6.5 & $3,14,16,17,18,24$ \\
\hline Cymodocea & angustata Ostenfeld & -10.7 & 1 & & & & & 17 \\
\hline Cymodocea & rotundata Ehrenb. \& Hempr. & -8.1 & 2 & 1.1 & -8.9 & -7.4 & 1.5 & 8,17 \\
\hline Cymodoced & nodosa (Ucria) Aschers. & -9.3 & 4 & 0.4 & -9.7 & -9.5 & 0.2 & 15,17 \\
\hline Cymodoced & serrulata (R. Br.) Aschers. \& Magnus & -10.7 & 3 & 2.3 & -12.4 & -8.0 & 4.1 & $8,12,17$ \\
\hline Amphibolss & antarctica (Labill.) Sonder \& Aschers. & -12.2 & 3 & 0.3 & -12.5 & -11.9 & 0.6 & 17,30 \\
\hline Amphibolis & griffithii (J.M. Black) den Hartog & -16.2 & 1 & & & & & 17 \\
\hline Thalassodendron & ciliatum (Forsk.) den Hartog & -12.4 & 9 & 4.5 & -19.7 & -5.3 & 14.4 & $15,17,29$ \\
\hline Thalassodendron & pachyrhizum den Hartog & -16.6 & 1 & & & & & 17 \\
\hline \multicolumn{9}{|l|}{ Zosteraceae } \\
\hline Zostera & marina $\mathrm{L}$. & -9.2 & 17 & 1.7 & -12.4 & -6.0 & 6.4 & $10,17,20,25$ \\
\hline Zosterd & caulescens Mikı & -9.7 & 1 & & & & & 17 \\
\hline Zostera & asiatica Miki & -12.8 & 1 & & & & & 17 \\
\hline Zostera & capricorni Aschers. & -10.8 & 2 & 2.3 & -12.4 & -9.2 & 3.2 & 12,17 \\
\hline Zostera & mucronata den Hartog & -9.9 & 1 & & & & & 17 \\
\hline Zostera & muelleri Irmisch ex Aschers. & -10.6 & 1 & & & & & 17 \\
\hline Zostera & capensis Setchell & -15.8 & 2 & 4.6 & -19.0 & -12.5 & 6.5 & 17 \\
\hline Zostera & novazelandica Setchell & -9.6 & 1 & & & & & 17 \\
\hline Zostera & noltii Hornem. & -11.6 & 2 & 0.5 & -12.0 & -11.3 & 0.7 & 17 \\
\hline Zostera & japonıca Aschers. \& Graebn. & -12.4 & 1 & & & & & 17 \\
\hline Zostera & amencana den Hartog & -15.3 & 1 & & & & & 17 \\
\hline Heterozostera & tasmanica (Martens ex Aschers.) den Hartog & -11.7 & 3 & 0.8 & -12.2 & -10.8 & 1.4 & 17,30 \\
\hline Phyllospadix & torreyi S. Watson & -13.1 & 3 & 2.2 & -14.3 & -10.5 & 3.8 & 3,17 \\
\hline Phyllospadix & scoulen Hook. & -12.8 & 4 & 1.3 & -14.4 & -11.4 & 3.0 & 17 \\
\hline Phyllospadix & serrulatus Rupr ex Aschers. & -15.4 & 3 & 2.7 & -18.5 & -13.6 & 4.9 & 17 \\
\hline Phyllospadix & iwatensis Makino & -15.8 & 1 & & & & & 17 \\
\hline Phyllospadix & japonicus Makino & -16.8 & 1 & & & & & 17 \\
\hline All species & & -11.5 & 48 & 3.2 & -20.8 & -5.8 & 15 & \\
\hline All observations & & -10.5 & 195 & 3.3 & -23.8 & -3.0 & 20.8 & \\
\hline
\end{tabular}


to temperate regions seagrass $\delta^{13} \mathrm{C}$ values tend to become more negative.

In the following sections we will address aspects of the physiology and the natural environment of seagrasses relevant to the distribution and variation in their $\delta^{13} \mathrm{C}$ values.

\section{PHYSIOLOGICAL CAUSES OF VARIABILITY}

\section{$\mathrm{C}_{3}$ versus $\mathrm{C}_{4}$ characteristics}

The isotope signatures of terrestrial plants predominantly fall in 2 distinct non-overlapping ranges related to the carbon fixing pathway used. Plants with the $C_{3}$ pathway of photosynthesis which fix inorganic carbon $\left(\mathrm{CO}_{2}\right)$ to ribulose-1,5-bisphosphate by ribulose-1,5bisphosphate carboxylase (Rubisco) have $\delta^{13} \mathrm{C}$ values from approximately -35 to $-20 \%$, the typical value of terrestrial $\mathrm{C}_{3}$ plants being around $-28 \%$ (with atmospheric $\mathrm{CO}_{2}$ at $-7.8 \%$ as source; Smith \& Epstein 1971 , Boutton 1991) These negative values are determined by the relatively strong isotopic discrimination which can be exerted by Rubisco (29 to $30 \%$ with respect to the source $\mathrm{CO}_{2}$ Roeske \& O'Leary 1984, Guy et al. 1987). In contrast, $\delta^{1.3} \mathrm{C}$ values of $\mathrm{C}_{4}$ plants which fix inorganic carbon $\left(\mathrm{CO}_{2}\right.$ hydrated to $\left.\mathrm{HCO}_{3}\right)$ to oxaloacetate range from -15 to $-9 \%$ (Ehleringer \& Osmond 1989). The primary carboxylase involved in these plants, phosphoenolpyruvate carboxylase (PEP carboxylase), shows an only limited discrimination against the heavy carbon isotope (O'Leary et al. 1981, Guy et al. 1989). Although the vast majority of seagrass isotope signatures fall in the range typical of $\mathrm{C}_{4}$ plants, the current belief is that seagrasses in general have the $\mathrm{C}_{3}$ type photosynthetic metabolism. This point of view is mainly based on the results obtained in ${ }^{14} \mathrm{C}$ pulselabeling experiments, which give insight into the pattern of organic compounds formed after photosynthetic $\mathrm{CO}_{2}$ incorporation. These studies have shown that nearly all seagrasses investigated (belonging to 8 different genera) show $\mathrm{C}_{3}$-like characteristics (Andrews \& Abel 1979, Beer \& Waisel 1979, Beer et al. 1980a, Benedict et al 1980, Beer \& Wetzel 1982), notwithstanding the fact that PEP carboxylase activity has been found in appreciable quantities in several seagrasses (Beer et al. 1980b). Pulse chase studies, however, showed that $\mathrm{C}_{4}$ compounds accumulated in the tissues and apparently did not provide $\mathrm{CO}_{2}$ to the second carboxylating step by Rubisco as occurs in terrestrial $\mathrm{C}_{4}$ plants (Beer 1989).

Insufficient data are presently available to assess the significance of PEP carboxylase and other comparably functioning enzymes for carbon assimilation in seagrasses. Studies carried out in phytoplankton and macroalgae show that even when inorganic carbon is mainly assimilated via Rubisco, other carboxylases may contribute to carbon fixation (Raven et al. 1990, Descolas-Gros \& Oriol 1992). Perhaps these enzymes only play a significant role in carbon fixation in seagrasses during specific conditions. In the nitrogen-limited $\mathrm{C}_{3}$ freshwater microalga Selenastrum minutum it was found that during nitrogen assimilation, discrimination against ${ }^{1.3} \mathrm{C}$ was greatly reduced (Guy et al. 1989). The authors attributed this to the increased importance of carbon fixation by PEP carboxylases, even exceeding carbon fixation by Rubisco under these conditions.

\section{Discrimination affected by diffusion versus carboxylation}

The $\mathrm{CO}_{2}$ assimilated by terrestrial plants enters the photosynthetic cells after diffusion of the $\mathrm{CO}_{2}$ from the air boundary layer surrounding the leaves through the stomatal pores. It has been widely noted that, besides fractionation caused by the carboxylation process, diffusive limitations may affect the isotope signature of the photosynthetic products. Several models have been developed to express isotopic discrimination; the general model of Farquhar et al. $(1982,1989)$ for discrimination in leaves of $\mathrm{C}_{3}$ plants has gained wide acceptance

$$
\Delta=a \frac{p_{\mathrm{a}}-p_{\mathrm{i}}}{p_{\mathrm{d}}}+b \frac{p_{\mathrm{i}}}{p_{\mathrm{d}}}
$$

where $\Delta$ indicates the carbon isotope discrimination by the plant relative to the source carbon, $a$ is the fractionation occurring due to diffusion of $\mathrm{CO}_{2}$ in air through the stomatal pore, $b$ the fractionation due to (Rubisco) carboxylation, and $p_{\text {a }}$ and $p_{1}$ are the ambient and intercellular (respectively) partial pressures of $\mathrm{CO}_{2}$.

The formula expresses the relative importance of isotopic discrimination associated with diffusion and with enzymatic carboxylation, in relation to ambient and internal concentrations of $\mathrm{CO}_{2}$. If $p_{1}$ is small relative to the ambient partial pressure of $\mathrm{CO}_{2}$ (which would occur when stomatal conductance is small in relation to the capacity for $\mathrm{CO}_{2}$ fixation), $\Delta$ would mainly be determined by differential diffusion of the ${ }^{13} \mathrm{C}$ and ${ }^{12} \mathrm{C}$ in the gas phase through the stomatal pore $\left(a_{1}-4.4 \%\right.$; Craig 1954).

The characteristically depleted $\delta^{13} \mathrm{C}$ values of $\mathrm{C}_{3}$ plants indicate that diffusion normally does not severely limit the carbon supply to terrestrial plants The situation in aquatic plants, however, is quite different. Diffusion rates of $\mathrm{CO}_{2}$ in water are much slower than in air, being different by 4 orders of magnitude. 
Each inorganic carbon molecule must cross a non-turbulent boundary layer by diffusion before entering the leaves, as even in turbulent or rapidly flowing water an unstirred layer envelops the leaves (Dainty 1963). Smith \& Walker (1980), in their review of the effects of unstirred layers on photosynthesis, demonstrated that the dependence of photosynthetic rate on $\mathrm{CO}_{2}$ concentration by charophyte cells was perfectly fitted by the Hill-Whittingham equation, which holds for a firstorder enzymatic reaction supplied with substrate by diffusion through a resistance. They concluded that the unstirred layers around aquatic plant cells and organs represent a major factor limiting their rate of photosynthesis under natural conditions. Consistent with their conclusion, Wheeler (1980) showed that the rate of photosynthetic oxygen production by the giant kelp Macrocystis pyrifera increased by $300 \%$ when water flow over the thalli increased from 0 to $4 \mathrm{~cm} \mathrm{~s}^{-1}$.

The occurrence of epiphytes on the thalli and leaves of aquatic macrophytes is a further impediment to the diffusional entry of $\mathrm{CO}_{2}$, as it results in an increased thickness of the unstirred boundary layer. As a consequence, the resistance to diffusional entry of $\mathrm{CO}_{2}$ may rise conspicuously (up to 11.5-fold; Sand-Jensen et al. 1985).

Accordingly, the characteristically high $\delta^{13} \mathrm{C}$ values of seagrasses are often thought to reflect primarily diffusional constraints on the carbon supply to the plant tissues relative to the demand for carbon fixation, which limits the expression of discrimination by Rubisco against ${ }^{13} \mathrm{C}$. It is noteworthy that recently France (1995), in a survey of stable carbon isotope signatures of benthic and planktonic algae, found that the average $\delta^{13} \mathrm{C}$ value for marine phytoplankton was $-22 \%$ compared to $-17 \%$ for marine benthic algae, a difference that was ascribed to the smaller boundary layer thickness of planktonic algae as compared to benthic algae. However, there is considerable evidence, discussed in the next section, that the use of bicarbonate may alleviate the carbon limitation which would be imposed on seagrass plants if they depended on the diffusion of dissolved $\mathrm{CO}_{2}$ alone.

\section{Use of bicarbonate in addition to dissolved carbon dioxide}

$\mathrm{HCO}_{3}{ }^{-}$in open marine waters generally has a $\delta^{13} \mathrm{C}$ value of ca $0 \%$, which is considerably higher than that of dissolved $\mathrm{CO}_{2}$ ( $\mathrm{Ca}-9 \%$; Kroopnick 1985). Fixation of bicarbonate-derived inorganic carbon relative to assimilation of dissolved $\mathrm{CO}_{2}$ thus leads to less ${ }^{13} \mathrm{C}$ depleted tissues. The limited ${ }^{13} \mathrm{C}$-depletion of seagrass tissues probably is caused, to some extent, by the assimilation of $\mathrm{HCO}_{3}{ }^{-}$instead of, or besides $\mathrm{CO}_{2}$. Par- ticularly the $\delta^{13} \mathrm{C}$ values higher than the $\delta^{13} \mathrm{C}$ of $\mathrm{CO}_{2}$ dissolved in seawater would be difficult to explain without the assimilation of $\mathrm{HCO}_{3}{ }^{-}$. The use of $\mathrm{HCO}_{3}{ }^{-}$ by seagrasses has been demonstrated in a series of species (Beer et al. 1977, Beer \& Waisel 1979, SandJensen \& Gordon 1984, Millhouse \& Strother 1986), and this faculty thus may be the rule in seagrasses. As yet, it is not certain whether there are exceptions: research on Thalassia testudinum first seemed to indicate that this species only uses dissolved $\mathrm{CO}_{2}$ as a carbon source (Benedict et al. 1980, Abel 1984), but a recent study, in contrast, gives evidence for the utilization of $\mathrm{HCO}_{3}^{-}$(Durako 1993). The use of $\mathrm{HCO}_{3}^{-}$in aquatic plants is widespread, in marine macroalgae (Maberly et al. 1992) and also in freshwater macrophytes, where approximately $50 \%$ of the species tested had this capacity (Bodner 1994). A feature that has come out of the research on these aquatic plants is the variation that may exist within the same species with respect to $\mathrm{HCO}_{3}{ }^{-}$use, and which may also be the basis for the above mentioned conflicting data on Thalassia testudinum. $\mathrm{HCO}_{3}{ }^{-}$utilization is not a rigid process with fixed properties, but a dynamic one tuned to the needs of the organism (Prins \& Elzenga 1989). $\mathrm{HCO}_{3}{ }^{-}$affinity, for instance, is highly variable in response to growth conditions and may be induced by low $\mathrm{CO}_{2}$ concentrations (Sand-Jensen \& Gordon 1986). Light conditions which reduce the demand for inorganic carbon may also influence the capacity for $\mathrm{HCO}_{3}{ }^{-}$uptake. In marine rhodophytes, transfer to low light conditions resulted in a change in the characteristics of inorganic carbon uptake (the initial uptake slopes being lower), and in decreased $\delta^{13} \mathrm{C}$ values (Kübler \& Raven 1994, cf. Kübler \& Raven 1995), likely resulting from repression of the ability for $\mathrm{HCO}_{3}^{-}$use. The capacity for $\mathrm{HCO}_{3}{ }^{-}$use, furthermore, may even be spatially different within the same plant. In the freshwater macrophyte Ranunculus peltatus, for instance, the submersed leaves are able to use $\mathrm{HCO}_{3}{ }^{-}$, but the emergent leaves only assimilate $\mathrm{CO}_{2}$ (Sand-Jensen et al. 1992). The underlying reason for the natural variation in $\mathrm{HCO}_{3}{ }^{-}$utilization may be the fact that it is energetically expensive (Raven \& Lucas 1985, Prins \& Elzenga 1989); hence, the maintenance of this ability is only advantageous when the supply of $\mathrm{CO}_{2}$ is limiting.

It is interesting that it appears to be possible to divide marine macroalgae into users and non-users of $\mathrm{HCO}_{3}{ }^{-}$ on the basis of their $\delta^{13} \mathrm{C}$ value: values below $-30 \%$ (particularly widespread in rhodophytes) indicate plants relying on diffusive entry of $\mathrm{CO}_{2}$ only, whereas those plants which also use $\mathrm{HCO}_{3}{ }^{-}$have values higher than -25\% (Maberly et al. 1992, Raven et al. 1995). If a similar division also held for seagrasses, the implication would be that seagrasses under natural conditions are always $\mathrm{HCO}_{3}^{-}$users, as all samples from field col- 
lections so far have yielded values well above $-25 \%$ (Fig. 1). The question thus would be not so much whether seagrasses are able to use $\mathrm{HCO}_{3}{ }^{-}$as source of inorganic carbon, but whether there are situations in which seagrasses only rely on diffusive entry of dissolved $\mathrm{CO}_{2}$ for their carbon supply.

The availability of $\mathrm{HCO}_{3}{ }^{-}$as an additional source of inorganic carbon will raise the inorganic carbon concentration at the site of carboxylation. According to the general Eq. (1) this would enhance the possibilities for discrimination by Rubisco. The situation, however, is probably less straightforward due to the variable degree of back-diffusion of inorganic carbon out of the plant cell. In terms of a chemical reaction chain the general rule is that when reactions go to completion (all substrate is converted to product) there is no opportunity for isotopic fractionation to occur. When a reversible equilibration occurs before a unidirectional reaction, isotopic fractionation depends on the backflow of the intermediate product versus the flow to the end product (for a more detailed discussion, see Peterson \& Fry 1987). Accordingly, Sharkey \& Berry (1985) linked the ratio of carbon backflow to carbon inflow with the discrimination of Rubisco in their model of discrimination in algae with a $\mathrm{HCO}_{3}$ transport mechanism. Applied to the marine environment, with the $\delta^{13} \mathrm{C}$ of $\mathrm{HCO}_{3}{ }^{-}$in the water being around zero, the $\delta^{13} \mathrm{C}$ values of $\mathrm{HCO}_{3}{ }^{-}$using algae would be determined by the ratio of carbon inflow and outflow according to the following equation (Surif \& Raven 1990):

$$
\delta^{13} \mathrm{C}=d_{\text {rub }} \frac{F_{3}}{F_{1}}
$$

where $d_{\text {rub }}$ is the kinetic discrimination by Rubisco, $F_{1}$ is the unidirectional influx of $\mathrm{HCO}_{3}{ }^{-}$into the cells, and $F_{3}$ the unidirectional efflux of $\mathrm{CO}_{2}$ out of the cells.

The ratio $F_{3} / F_{1}$ (indicative for the 'leakiness' of the plant cells) has been calculated to be in the range 0.5 to 0.8 for a number of macroalgae with $\delta^{13} \mathrm{C}$ values between circa -15 and $-22 \%$ (Surif \& Raven 1990, Maberly et al. 1992). Following the same calculation model (Eq. 2), for $\mathrm{HCO}_{3}{ }^{-}$using seagrasses with a $\delta^{13} \mathrm{C}$ of $-10 \%$ the ratio would be considerably smaller (0.3). We are not aware of studies specifically addressing the 'leakiness' of seagrasses in relation to carbon isotope signatures. In several papers, however, the lacunal system of the leaves has been proposed to act as a $\mathrm{CO}_{2}$ trap which promotes recycling of the internal $\mathrm{CO}_{2}$ pool, whether derived from respiration or from the ambient water (Cooper 1989, Abal et al. 1994, Grice et al. 1996). According to the authors, enhanced lacunal. development in the leaves (such as may occur when plants grow in anoxic sediments or at increased light intensities) would lead to a greater use of the internal pool of $\mathrm{CO}_{2}$, and consequently, to less isotopic discrim-
Table 2. Relative volume of the leat lacunal system ( $\%$ of total leaf volume) and $\delta^{13} \mathrm{C}$ values in seagrasses. Data on leaf lacunal volumes (\%) are derived from Larkum et al. (1989). Stable carbon isotope signatures from the various species (means of 1 to 8 observations) are denved from the compiled literature data set (see Table 1)

\begin{tabular}{|lcr|}
\hline Species & $\begin{array}{c}\text { Relative lacunal } \\
\text { volume }\end{array}$ & $\delta^{1.5} \mathrm{C}$ \\
\hline Halophila ovalis & 2.7 & -10.0 \\
Posidonia ostenfeldii & 4.8 & -12.0 \\
Amphibolis antarctica & 16.0 & -12.2 \\
Halodule uninervis & 25.6 & -11.2 \\
Posidonia australis & 27.9 & -9.9 \\
Zostera capricomi & 45.7 & -10.8 \\
\hline
\end{tabular}

ination. The enhanced recycling ascribed to the presence of the lacunal system would be the equivalent of reducing the 'leakiness' of the plant cells, and, hence, the flux $F_{3}$ in Eq. (2). A comparison across species, however, does not support the importance of the lacunal system in determining the $\delta^{13} \mathrm{C}$ values of seagrasses: although the relative volume of the system in the leaves of various seagrass species may differ by more than an order of magnitude, the isotope values established so far in these species are in a similar range (Table 2). Therefore, apart from studies more specifically addressing the role of the lacunal system in restricting the efflux of inorganic carbon from the leaves, future investigations should also be focussed on the possibility that physiological or anatomical barriers restricting efflux of inorganic carbon may exist in the photosynthetic cells themselves.

\section{Uptake of inorganic carbon from air and soil}

Intertidal populations of the genus Zostera appear to have the capacity to absorb $\mathrm{CO}_{2}$ from the atmosphere during emersion at low tides. Studies on $Z$. muelleri (Clough \& Attiwill 1980) and $Z$. marina and Z. noltii (Leuschner \& Rees 1993) showed that these species were able to maintain considerable rates of net photosynthesis during low ticle exposure, as could be derived from measurements of $\mathrm{CO}_{2}$ uptake. The use of 'light' atmospheric $\mathrm{CO}_{2}(-7.8 \%)$ instead of $\mathrm{HCO}_{3}{ }^{-}$was given as the most likely reason for the relatively ${ }^{13} \mathrm{C}$-depleted character of biomass produced by periodically air-exposed populations of Phyllospadix torreyi, Phyllospadix serrulatus and Zostera marina (Cooper \& McRoy 1988, Cooper 1989). Perhaps more likely, the presumably decreased diffusive boundary layer thickness during emersed conditions leads to an increased supply of $\mathrm{CO}_{2}$ to the photosynthetic cells, allowing enhanced discrimination against 
the heavy isotope. The periodical availability of atmospheric $\mathrm{CO}_{2}$ nonetheless appears to have an only limited effect on the stable carbon isotope signature: both in the aforementioned studies on seagrasses and in an analysis of emergent macroalgae (Surif \& Raven 1990), tidal emersion appeared to lower the $\delta^{13} \mathrm{C}$ value by only 1 to $4 \%$.

Another potential source of inorganic carbon is the sediment, where mineralization processes generate $\mathrm{CO}_{2}$. The elaborate system of lacunae in seagrasses which interconnects roots, rhizomes and leaves is a pathway for gas movements within the plant (Larkum et al. 1989). Via the lacunae, the photosynthetic tissues aboveground thus potentially may be provided with $\mathrm{CO}_{2}$ taken up by the roots. Alternatively, $\mathrm{CO}_{2}$ derived from the sediment could be transported with the acropetal water transport from roots to leaves (Pedersen \& Sand-Jensen 1993). Indeed, Wetzel \& Penhale (1979) showed that ${ }^{14} \mathrm{C}$-label from $\mathrm{HCO}_{3}{ }^{-}$, which was added to the root compartment of various species of seagrasses, was largely recovered in the water of the leaf compartment, indicating upward transport; a comparatively small amount was retained in the leaf tissue itself. No other studies on the use of carbon taken up by seagrass roots appear to have been published so far Uptake of soil inorganic carbon has been established in some freshwater plants, allowing them to grow in water of low inorganic carbon content (e.g. Richardson et al. 1984), and in unusual fern allies, which lack stomata (Keeley et al. 1984, Sternberg et al. 1985). However, the assimilation of soil carbon is clearly more the exception than the rule in rooting plants (Agami \& Waisel 1986, Enoch \& Olesen 1993), and its occurrence in seagrasses remains doubtful.

\section{ENVIRONMENTAL CAUSES FOR VARIABILITY}

\section{Source carbon}

The isotopic signature of the inorganic carbon available for photosynthesis is of major importance in determining plant $\delta^{13} \mathrm{C}$ values. As mentioned above, the $\delta^{13} \mathrm{C}$ values of dissolved $\mathrm{CO}_{2}$ and $\mathrm{HCO}_{3}^{-}$in open marine waters are usually around $-9 \%$ and $0 \%$, respectively (Kroopnick 1985). In estuarine and other coastal environments which receive land run-off, however, considerably lower $\delta^{13} \mathrm{C}$ values can be expected. The inorganic carbon pool in these areas is influenced by the input of ${ }^{13} \mathrm{C}$-depleted carbon derived from the decomposition of terrestrial organic matter. Such inputs may account for an important part of the variability observed in seagrass $\delta^{13} \mathrm{C}$ values. The best documented examples of the effect of land run-off on seagrass $\delta^{13} \mathrm{C}$ values are provided by studies of sea-

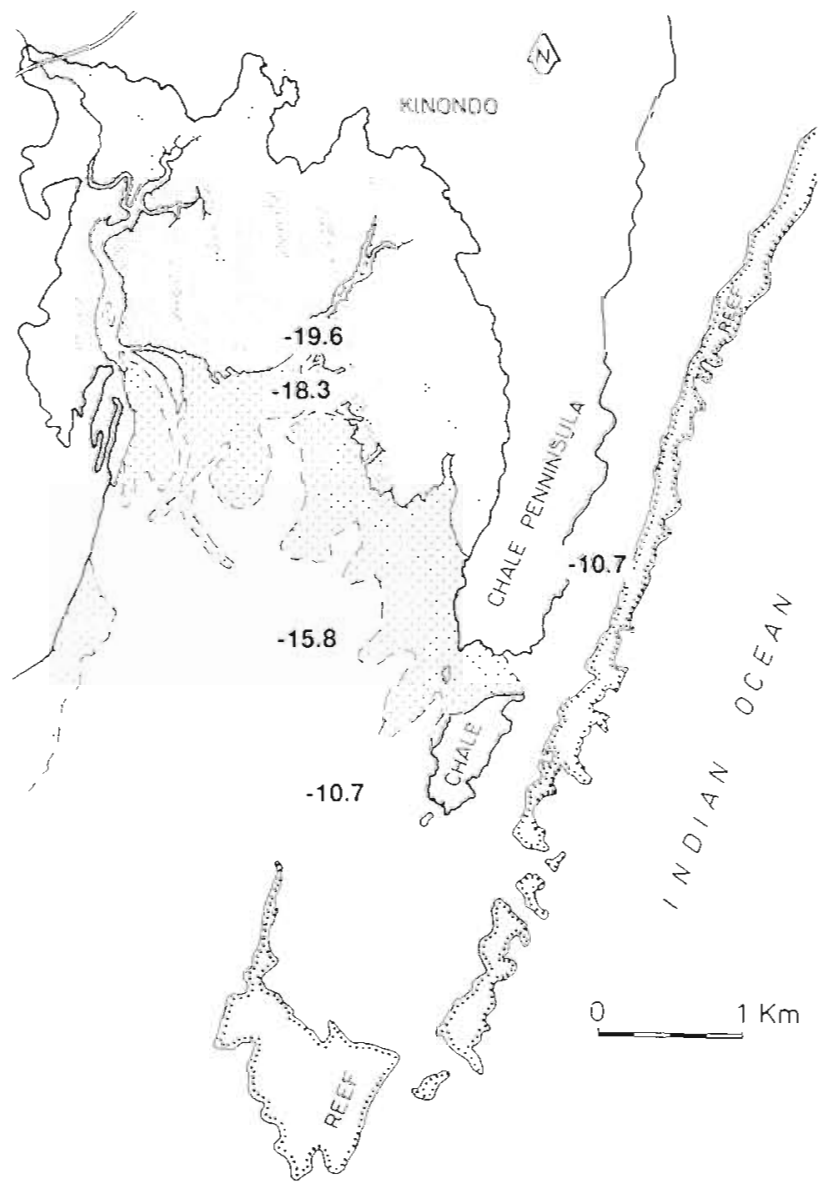

Fig. 3. Map of Gazi Bay (Kenya), showing variation of $\delta^{13} \mathrm{C}$ values (means of 4 pooled leaf samples) of Thalassodendron ciliatum in relation to distance to the mangrove forest (heavy stippling). Light stippling indicates intertidal flats. Data from Hemminga et al. (1994)

grass meadows adjacent to mangrove forests. The $\delta^{13} \mathrm{C}$ values of mangroves are generally in the range -30 to $-24 \%$ (Rodelli et al. 1984, Rao et al. 1994), i.e. in the typical range of $\mathrm{C}_{3}$ plants. Mineralization of mangrove litter will result in the formation of $\mathrm{CO}_{2}$ with a $\delta^{13} \mathrm{C}$ value close to the $\delta^{13} \mathrm{C}$ values of living mangrove biomass, as little change in the isotopic composition seems to occur during senescence and decomposition (Zieman et al. 1984, Rao et al. 1994). This ${ }^{13} \mathrm{C}$-depleted inorganic carbon, dissolved in the tidal water inundating the mangrove forest and subsequently captured by adjacent seagrass meadows, may result in comparatively ${ }^{13} \mathrm{C}$-depleted seagrass isotope signatures. Data of Hemminga et al. (1994) show that seagrass $\delta^{13} \mathrm{C}$ values rapidly become more negative (by as much as $9 \%$ ) with decreasing distance from a mangrove forest (Fig. 3). Other authors have also reported low values in mangrove areas compared to non-mangrove areas (Zieman et al. 1984, Fleming et al. 1990, Lin et al. 
1991). Indeed, the most negative value reported for a seagrass until now $(-23.8 \%)$ was found in Halophila beccarii collected in a mangrove creek (McMillan et al. 1980). The magnitude of the mangrove input into the tidal water inundating the mangrove is subject to seasonal variations and tidal patterns (Rezende et al. 1990), but the effects of these phenomena on seagrass $\delta^{13} \mathrm{C}$ values is not known.

Important riverine inputs of terrestrial materials can also affect the isotopic ratio of estuarine seagrasses as shown by Simenstad \& Wissmar (1985). $\delta^{13} \mathrm{C}$ values of Zostera marina were lower in meadows on an estuarine tidal flat than in the ones occurring in marine littoral areas. The difference in samples from both environments was higher in winter than in summer (ca $6 \%$ and $3 \%$, respectively), probably reflecting a higher riverine discharge into the estuary during winter time.

\section{Irradiance}

It should be noted that in both models of discrimination formalized in Eqs. (1) \& (2), the balance between inorganic carbon supply and inorganic carbon use can be expected to have a profound influence on the isotopic discrimination. In Eq. (1), the fixation of inorganic carbon will lower $p_{1}$ relative to $p_{\mathrm{a}}$ and in Eq. (2), backdiffusion of $\mathrm{CO}_{2}\left(F_{3}\right)$ will be limited by fixation of this compound during photosynthesis. Hence, both models predict decreased isotopic fractionation during carboxylation by Rubisco under conditions of enhanced photosynthesis and growth. Evidence that light affects the $\delta^{13} \mathrm{C}$ values of aquatic plants has been provided repeatedly. Wefer \& Killingley (1986) found that specimens of the macroalga Halimeda incrassata growing in shallow waters were less depleted in ${ }^{13} \mathrm{C}$ than the ones growing in deeper waters. Fischer \& Wiencke (1989) found a similar pattern in Antarctic algae growing along a bathymetric gradient. They observed that species growing in deep waters with low growth rates had values of about $-30 \%$ while fast-growing algae occurring at shallower depths had much higher values $(c a-10 \%)$. Laboratory experiments with several species subsequently showed strong ${ }^{13} \mathrm{C}$ enrichments (10 to $25 \%$ ) with increasing photon flux rates (Wiencke \& Fischer 1990). Furthermore, the $\delta^{13} \mathrm{C}$ values of the rhodophyte Palmaria palmata showed a positive, linear correlation with irradiance in the range of 5 to $125 \mu \mathrm{mol}$ photons $\mathrm{m}^{-2} \mathrm{~s}^{-1}$, increasing from -18.4 to $-12.5 \%$ (Kübler \& Raven 1995).

Data on seagrasses also indicate that increasing irradiance leads to diminished isotopic discrimination. Cooper \& DeNiro (1989) reported decreasing $\delta^{1.3} \mathrm{C}$ values in entire leaves of Posidonia oceanica with increas- ing depths, from $-11 \%$ at $5 \mathrm{~m}$ depth to $-16.4 \%$ at $35 \mathrm{~m}$ depth. No other factor but light attenuation could adequately explain these differences. The relation between $\delta^{13} \mathrm{C}$ values and depth was most pronounced when the distal parts of the leaves were considered, but was lost for the leaf parts closest to the meristem. This was attributed to interference with the shading effect of the canopy. ${ }^{13} \mathrm{C}$-depletion was also observed in response to experimental light reduction in beds of Thalassia testudinum (Durako \& Hall 1992) and in mesocosmos experiments with Zostera capricomi (Abal et al. 1994). Most convincingly, Grice et al. (1996) recently reported that leaves of 5 seagrass species each showed increased $\delta^{13} \mathrm{C}$ values when grown in seawater aquaria at higher light intensities. The $\delta^{13} \mathrm{C}$ values, furthermore, were significantly correlated with productivity rates of the seagrasses.

The straightforward relation between light and sta ble carbon isotope signature in seagrasses which emerges from the currently published data, may prove to be more complicated when additional information becomes available. A reversed response of $\delta^{13} \mathrm{C}$ to light intensity, for instance, has recently been described in 2 phytoplankton species grown in laboratory batch cultures (Thompson \& Calvert 1995). Phytoplankton species may be able to increase the $\mathrm{CO}_{2}$ concentration at the carboxylation site of Rubisco by actively taking up $\mathrm{HCO}_{3}$ ' when necessary (Raven \& Johnston 1991). Thompson \& Calvert (1995) pointed out that if uptake increased as a function of increasing irradiance but the carboxylation rate would not increase to a similar extent, the elevated levels of $\mathrm{CO}_{2}$ at the carboxylation site could lead to intensified isotopic discrimination.

Isotopic discrimination may also be affected by a complex interaction between light intensity and daylength. The Antarctic/cold temperate macroalgal species Adenocystis utricularis showed no significant variation in $\delta^{13} \mathrm{C}$ values in the irradiance range of 10 to $45 \mu \mathrm{mol} \mathrm{m} \mathrm{m}^{-2} \mathrm{~s}^{-1}$ at a light/dark cycle of $6: 18 \mathrm{~h}$, whereas at a $18: 6 \mathrm{~h}$ light/dark cycle $\delta^{13} \mathrm{C}$ increased from ca -20 to $-15 \%$ (Wiencke \& Fischer 1990) Thompson \& Calvert (1994), in a study of the diatom Thalassiosira pseudonana cultured in different light/dark cycles, found that discrimination was highest when the algae were cultured at cycles of 16:8 and 20:4 h. Furthermore, they found a highly significant interaction between daylength and light intensity associated with ca $4 \%$ of the variation in ${ }^{13} \mathrm{C}$ discrimination by the diatom. Differences in the activity ratios of the various carboxylases may be involved in these phenomena: Cosper (1982) and Descolas-Gros \& Oriol (1992) found that in phytoplankton both daylength and irradiance intensity influenced the proportion of carbon fixed by 3 -carboxylation relative to that fixed by Rubisco carboxylation. 


\section{Temperature}

In Fig. 2 we showed that a negative correlation exists between the $\delta^{13} \mathrm{C}$ values of seagrasses and their corresponding geographical sampling latitude. Rau et al. (1989) found a similar relation for plankton in the South Antlantic Ocean and Weddell Sea. The authors attributed the highly significant decrease of $\delta^{1,3} \mathrm{C}$ values with increasing latitude to the effect of temperature on $\mathrm{CO}_{2}$ solubility and, hence, concentration in seawater They calculated the $\mathrm{CO}_{2}$ concentration in seawater $\left(\mathrm{CO}_{2(\alpha q)}\right)$ by considering the temperaturesensitive $\mathrm{CO}_{2}$ solubility described by the equation:

$$
\mathrm{CO}_{2 \mid \mathrm{a}(1)}=a \times p \mathrm{CO}_{2}
$$

where $a$ is the $\mathrm{CO}_{2}$ solubility constant, which is a function of both salinity and temperature, and $p \mathrm{CO}_{2}$ is the atmospheric partial pressure of $\mathrm{CO}_{2}$ at sea level. $\mathrm{CO}_{2(a q)}$ increases with decreasing temperatures, being ca 2.5 times higher at $60^{\circ} \mathrm{S}$ than near the equator. According to the authors, the positive relationship between carbon availability and carbon isotope discrimination presumed in current models explains the lighter carbon composition of Antarctic plankton. However, laboratory experiments with phytoplankton cultures failed to reproduce such variations, although much wider ranges of $\mathrm{CO}_{2 \text { (aq) }}$ were used (Thompson \& Calvert 1994 and references therein, Thompson \& Calvert 1995). Furthermore, macroalgae grown at a temperature range of 0 to $25^{\circ} \mathrm{C}$ did not show continuous isotope changes (Wiencke \& Fischer 1990).

Lower temperatures, in principle, would tend to increase the $\delta^{13} \mathrm{C}$ of dissolved inorganic carbon (DIC) in the seawater as ${ }^{13} \mathrm{C}$-fractionation between atmospheric $\mathrm{CO}_{2}$ and DIC increases with falling temperatures (ca $1 \%$ per $10^{\circ} \mathrm{C}$; Mook et al. 1974, Zhang et al. 1995). This tendency is not consistent with the latitudinal change in isotope signatures found in seagrasses and, obviously, cannot offer an explanation for it.

To the best of our knowledge, no specific information concerning temperature effects on the carbon isotopic composition of seagrasses is presently available, and therefore the observed relation between stable carbon isotope signatures and latitude cannot be explained with certainty. However, Durako \& Sackett (1993) observed that Thalassia testudinum conspicuously reacted to experimentally manipulated levels of dissolved $\mathrm{CO}_{2}$, fractionation of the stable carbon isotopes increasing as a function of $\mathrm{CO}_{2(\text { aq) }}$. The effect of temperature on $\mathrm{CO}_{2}$ availability in seawater thus seems to offer presently the most plausible explanation for the latitudinal trend in seagrass $\delta^{13} \mathrm{C}$ values, but gradients in irradiance and daylength may also be involved. Irrespective of its cause, the relationship shown in Fig. 2 suggests that the balance between carbon availability and carbon fixation in seagrasses shifts with geographical latitude, with a higher proportion of the inorganic carbon supplied to the carboxylation site fixed at lower geographical latitudes.

\section{APPLICATIONS OF STABLE CARBON ISOTOPES IN SEAGRASS ECOLOGY}

The limited use of stable carbon isotopes in studies of seagrass ecology is perhaps not surprising considering the fact that a number of factors potentially may cause variability in $\delta^{13} \mathrm{C}$ values, whereas the impact of these factors often is ill-defined. A better understanding of this complex matter is certainly a prerequisite for further development of stable carbon isotope analysis as a tool in the study of seagrass ecology. Nonetheless, possibilities for applications already exist. In the following sections, the established application of stable carbon isotopes in food web studies is briefly addressed along with potential applications whose contours are emerging from the now available information.

\section{Carbon flow in food webs}

The $\delta^{13} \mathrm{C}$ value of animals reflects the organic matter they assimilate, which has made stable carbon isotopes a valuable tool in the study of trophic relations. The pioneering work of Haines (1976a, b), who used stable carbon isotopes to elucidate the carbon flow in the salt marsh food web, was followed by a series of papers addressing trophic relations in seagrass ecosystems. Some of these studies indicated the use of seagrass derived carbon by fauna in the seagrass system (Fry \& Parker 1979, McConnaughey \& McRoy 1979, Fry et al. 1983, Harrigan et al. 1989), whereas others did not (Thayer et al. 1978, Fry 1984). As has frequently been pointed out, the use of isotope signatures to trace carbon flow is dependent upon there being clear and consistent differences in the isotopic composition of the various classes of primary producers. These conditions are not always met in seagrass systems. Fry et al. (1982), who studied Caribbean seagrass meadows, for instance, found that the isotopic values of a large proportion of the algal species sampled were in the same range as the dominant seagrass species, Thalassia testudinum; this prevented assessment of the role of this seagrass in the local food web on the basis of $\delta^{13} \mathrm{C}$ only. Furthermore, the source carbon may show seasonal variation in its isotopic signature (Smith \& Epstein 1971, Simenstad \& Wissmar 1985). The scanty information available suggests that seasonal variation in seagrass $\delta^{13} \mathrm{C}$ values may be rather limited (1 to $4 \%$; Thayer et al. 1978, Fry 1984, Stephenson et al. 1984), 
but data collected in other aquatic ecosystems show much more variation (Boon \& Bunn 1994), and preclude convenient assumptions that could be made. In addition, as discussed above, the isotopic signature of seagrasses may vary locally in response to environmental factors such as the depth-associated light gradient (2 to 6\%; Cooper \& DeNiro 1989, Durako \& Hall 1992). Obviously, the use of stable carbon isotopes for the study of carbon flow in food webs has its own pitfalls and limitations. The analysis of other stable isotopes besides carbon (nitrogen, sulphur) can significantly improve the possibilities of unravelling trophic relations (Peterson \& Howarth 1987), but appears not to have been attempted in seagrass systems.

\section{Temporal changes in seagrass functioning}

As has been described by Tomlinson (1974) and more recently by Duarte et al. (1994), seagrasses grow by the reiterative development of 3 types of modules: rhizome internodes (which lead to extension of the plant in vertical or horizontal directions), leaves and roots. Leaves develop from meristems at the rhizome apices. After leaf senescence and subsequent loss, the insertion points of the leaves on the rhizome remain identifiable as scars (nodes). Due to seasonally changing environmental conditions, the internodes along rhizomes often display regular patterns of alternating waves of short and long internodal lengths (Duarte et al 1994). In a species such as Posidonia oceanica, the leaf sheaths remain attached to the rhizome long after the leaf blades have been fallen from the plant. Sheath thickness in this species also shows seasonal variation (Boudouresque et al. 1983). The seasonal signals detected in internodal lengths or in sheath thickness allows absolute dating of rhizome pieces of many seagrass species, up to several decades BP. The rhizomes thus present a fascinating historical archive allowing the present-day researcher to draw conclusions on e.g. primary productivity and aspects of population dynamics in past years (Duarte et al. 1994, Pergent-Martini \& Pergent 1994). Stable carbon isotope data on rhizome time series may provide additional information on seagrass functioning For instance, in Thalassodendron ciliatum growing in a Kenyan lagoon we observed that the first-formed (often 3 to $5 \mathrm{yr}$ old) parts of the vertical rhizomes bearing the leaf clusters had more depleted $\delta^{13} \mathrm{C}$ values ( $\mathrm{Ca}-13 \%$ ) than the parts formed in subsequent years ( $\mathrm{ca}-10 \%$ ) (Slim \& Hemminga unpubl.). These data suggest that growth of young shoots is light-limited (the reduced carbon demand relative to the carbon supply allowing a higher level of isotopic discrimination), and explain the extended length of the first (oldest) internodes which serve to bring the young

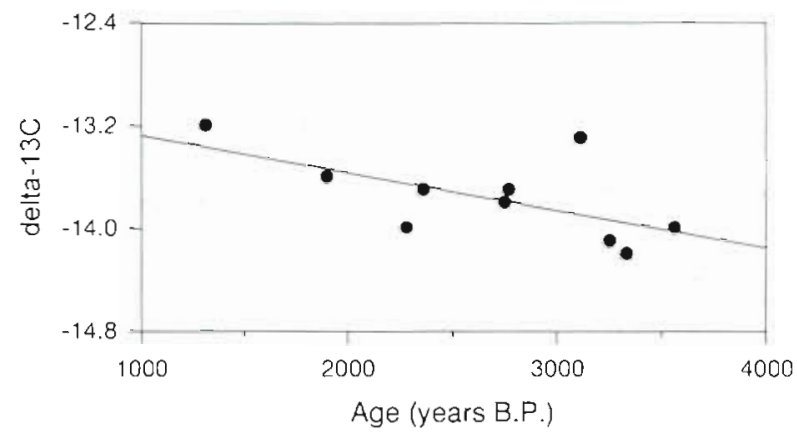

Fig. $4 . \delta^{13} \mathrm{C}$ values of samples taken from a Posidonia oceanica matte (Medes Islands, Spain) as a function of their corresponding radiocarbon age ( $y$ r $B P$ ). The regression line fitted to the data $(r=0.62, p=0.054)$ is described by the formula $\delta^{13} \mathrm{C}=-12.981-0.00029$ age. Dotted lines indicate $95 \%$ confidence interval

leaf cluster rapidly to canopy height where high light conditions prevail.

Stable carbon isotope signatures may be informative over longer time scales as well. In the case of Posidonia oceanica it has been established that dead sheaths and rhizomes decompose very slowly in the sediment and may persist for millennia, forming a so-called 'matte' (Boudouresque et al. 1980, Romero et al. 1994, Mateo et al. 1996j. Fig. 4 shows data from one of us (M.A.M.) on the $\delta^{13} \mathrm{C}$ values of samples taken along a depth profile of such a 'matte' near the Medes Islands (Spain) in the Mediterranean. The absolute age of the samples was established by dendrocalibrated ${ }^{14} \mathrm{C}$-radiocarbon dating. The samples cover a period of nearly $2500 \mathrm{yr}$ but their $\delta^{13} \mathrm{C}$ values only differ by $1 \%$ or less. This uniformity in $\delta^{13} \mathrm{C}$ values strongly suggests stable functioning (similar growth rates) of this Posidonia population over thousands of years. The very slight (but significant) increase in $\delta^{13} \mathrm{C}$ values with decreasing age of the samples may point to a slow change in the meadow environment, e.g. seawater temperature or irradiance, affecting the balance between carbon supply and carbon use, or to preferential degradation of ${ }^{13} \mathrm{C}$-rich organic compounds.

\section{Use of ${ }^{13} \mathrm{C}$ as an experimental tracer}

Plants can be exposed, both in the laboratory and in the field, to an environment enriched in ${ }^{13} \mathrm{C}$-inorganic carbon. ${ }^{13} \mathrm{C}$ subsequently can be used as a tracer of carbon flow in the clonal structure of the plant. Earlier studies have shown the potential usefulness of ${ }^{13} \mathrm{C}$ for the assessment of carbon allocation in individual terrestrial plants (Mordacq et al. 1986, Svejcar et al. 1990). Recently, the proportional allocation of photosynthetically-fixed carbon to the roots and shoot sys- 
tem of the salt marsh halophyte Spartina anglica was measured in the natural field situation after exposing leaves and stems briefly $(1 \mathrm{~h})$ to $\mathrm{CO}_{2}$ enriched in ${ }^{13} \mathrm{C}$ (Hemminga et al. 1996). Adaptations of this procedure may also be used in studies of seagrasses. Durako \& Sackett (1991) perfused a seawater medium in cylinders containing seedlings of Thalassia testudinum with gaseous $\mathrm{CO}_{2}$ strongly depleted in ${ }^{13} \mathrm{C}\left(\delta^{13} \mathrm{C}=-49.6 \%\right)$; this resulted in plants with an overall $\delta^{13} \mathrm{C}$ of $-57.1 \%$. Similarly, it can be expected that short-term perfusion of an ambient medium with ${ }^{13} \mathrm{C}$-enriched $\mathrm{CO}_{2}$, or incubation with dissolved ${ }^{13} \mathrm{C}$-enriched bicarbonate, will lead to ${ }^{1.3} \mathrm{C}$-enrichment of growing plant structures. We expect that, in this way, it will be possible to study patterns in carbon allocation in seagrasses, for instance in relation to changing environmental conditions.

${ }^{13} \mathrm{C}$ may possibly also be useful for short-term measurements of photosynthesis. Studies with phytoplankton have shown that there is a good agreement between primary productivity measurements carried out with the conventional ${ }^{14} \mathrm{C}$ method and with ${ }^{13} \mathrm{C}$ (Slawyk et al. 1984, Mousseau et al. 1995). The advantage of the use of ${ }^{13} \mathrm{C}$ above that of ${ }^{14} \mathrm{C}$ is obviously that its use requires no specific safety precautions or permission, and, in principle, can be used without environmental risks. The investigator, however, should be aware of the discrimination against ${ }^{13} \mathrm{C}$, which in certain situations, e.g. when rates of incorporation in specific organic molecules are studied, could complicate the interpretation of the results. A second, more general, caveat with respect to the use of ${ }^{13} \mathrm{C}$ as an experimental tracer is that such work should be clearly spatially separated from studies on natural isotopic abundance (both in the field and in the laboratory) to avoid erroneous sample values.

\section{FINAL REMARKS}

As we have shown in this review, the range of seagrass $\delta^{13} \mathrm{C}$ values is substantial, but considerably smaller than that of other aquatic macrophytes. In comparison to freshwater plants the difference will be caused by the fact that the source inorganic carbon in the marine environment, in general, is less variable than in lakes and streams. Why the range is less in comparison to marine macroalgae can only be a matter of speculation; it may be related to the widespread use of $\mathrm{HCO}_{3}{ }^{-}$as a source of inorganic carbon along with dissolved $\mathrm{CO}_{2}$. Equally intriguing is the fact that seagrasses typically have a high $\delta^{13} \mathrm{C}$ of $-10 \%$. This clearly points to a characteristic set of determining physiological, anatomical and perhaps environmental features shared by all seagrasses. If we assume that the balance between carbon supply and carbon fixation is a key element in the process of isotopic fractionation, it suggests that inorganic carbon taken up from the environment normally is fixed to a relatively large extent, restricting discrimination by Rubisco. It is as yet doubtful whether the lacunal system is an anatomical feature relevant in this respect. Obviously, elucidating the discriminating properties of seagrasses will go hand in hand with clarification of functionally important aspects of carbon use and dynamics in these marine plants.

Based on the now avallable information, the 3 most significant environmental factors inducing variation in seagrass $\delta^{13} \mathrm{C}$ values appear to be, in order of decreasing importance: source carbon, irradiance and temperature. However, other factors which may also induce variation, because they are expected to influence the balance between carbon availability and carbon fixation rates (e.g. ambient water flow and nutrient levels, Abel \& Drew 1989), have not been specifically investigated until now.

The various environmental factors that influence the stable carbon isotope signature in seagrasses can be considered both a limitation and an asset for studies of seagrass ecology. Spatial and temporal variability in seagrass $\delta^{13} \mathrm{C}$ values restricts, for instance, the use in food web studies. On the other hand, as we have illustrated, the integrated information reflected in seagrass stable carbon isotope signatures can be used in support of the reconstruction of environmentally related growth dynamics on the scale of individual shoots or on that of entire populations.

Acknowledgements. The authors thank J. B. M. Middelburg, T E. Cappenberg, A. H. L. Huiskes, J. Romero and 4 anonymous reviewers for their critical remarks and comments which helped to improve the manuscript. Thus is NIOOCEMO publication no. 2162 .

\section{LITERATURE CITED}

Abal EG, Loneragan N, Bowen P, Perry CJ, Udy JW, Dennison WC (1994) Physılogical and morphological responses of the seagrass Zostera Capricorni Aschers to light intensity. J Exp Mar Biol Ecol 178:113-129

Abel KM (1984) Inorganic carbon source for photosynthesis in the seagrass Thalassia hempnchii (Ehrenb) Aschers. Plant Physiol 76:776-781

A.bel KM, Drew EA (1989) Carbon metabolism. In: Larkum AWD, McComb AJ, Shepherd SA (eds) Biology of seagrasses. Elsevier, Amsterdam, p 760-796

Agami M, Waisel Y (1986) The ecophysiology of roots of submerged vascular plants. Physiol Vég 24:607-624

Andrews TJ, Abel KM (1979) Photosynthetic carbon metabolism in seagrasses. Plant Physiol 63:650-656

Beer S (1989) Photosynthesis and photorespiration of marine angiosperms. Aquat Bot 34:153-166

Beer S, Eshel A, Waisel Y (1977) Carbon metabolism in seagrasses I. The utilization of exogenous inorganic carbon species in photosynthesis. J Exp Bot 28:1180-1189 
Beer S, Eshel A, Waisel Y (1980b) Carbon metabolism in seagrasses III. Activities of carbon-fixing enzymes in relation to internal salt concentrations. J Exp Bot 31:1027-1033

Beer S, Shomer-llan A, Wassel Y (1980a) Carbon metabolism in seagrasses II. Patterns of photosynthetic $\mathrm{CO}_{2}$ incorporatıon. J Exp Bot 31:1019-1026

Beer S, Waisel Y (1979) Some photosynthetic carbon fixation properties of seagrasses. Aquat Bot 7:129-138

Beer S, Wetzel RG (1982) Photosynthetic carbon fixation pathways in Zostera marina and three Florida seagrasses. Aquat Bot 13:141-146

Bell JD, Pollard DA (1.989) Ecology of fish assemblages and fisheries associated with seagrasses. In: Larkum AWD, McComb AJ, Shepherd SA (eds) Biology of seagrasses. Elsevier, Amsterdam, p 565-597

Benedict CR, Scott JR (1976) Photosynthetic carbon metabolism of a marıne grass. Plant Physiol 57:876-880

Benedict CR, Wong WWL, Wong JHH (1980) Fractionation of the stable isotopes of inorganic carbon by seagrasses. Plant Physiol 65:512-517

Black CC, Bender MW (1976) $\delta^{13} \mathrm{C}$ values in marine organisms from the Great Barrier Reef. Aust J Plant Physiol 3: 25-32

Bodner M (1994) Inorganic carbon source for photosynthesis in the aquatic macrophytes Potamogeton natans and Ranunculus fluitans. Aquat Bot 48:109-120

Boon PI, Bunn SE (1994) Variations in the stable isotope composition of aquatic plants and their implications for food web analysis. Aquat Bot 48:99-108

Boudouresque CF, Crouzet A. Pergent G (1983) Un nouvel outil au service de l'étude des herbiers à Posidonia oceanica: la lêpidochronologie. Rapp PV Réun Comm Int Explor Sci Médit, Monaco 28:111-112

Boudouresque CF, Giraud G, Thommeret J, Thommeret Y (1980) First attempt at dating by ${ }^{\mathrm{I}} \mathrm{C}$ the undersea beds of dead Posidonia oceanica in the bay of Port-Man (PortCros, Var, France). Trav Sci Parc Natl Port-Cros Fr 6: $239-242$

Boutton TW (1991) Stable carbon isotope ratios of natural materials II: Atmospheric, terrestrial, marine, and freshwater environments. In: Coleman DC. Fry B (eds) Carbon ssotope techniques. Academic Press, San Diego, p $137-186$

Clough BF, Attiwill PM (1980) Primary productivity in Zostera muelleri Irmisch. ex Aschers in Westernport Bay (Victoria, Australiaj. Aquat Bot 9:1-13

Cooper LW (1989) Patterns of carbon isotopıc variability in eelgrass, Zostera marnna L. from Izembek lagoon, Alaska. Aquat Bot 34:329-339

Cooper LW, DeNiro MJ (1989) Stable carbon isotope variability in the seagrass Posidonid oceanica: evidence for light intensity effects. Mar Ecol Prog Ser 50:225-229

Cooper LW, MCRoy CP (1988) Stable carbon isotope ratio vanations in marine macrophytes along intertidal gradients. Oecologia 77:238-241

Cosper E (1982) Intluence of light intensity on diel variations in growth, respiration and organic release of a marine diatom: comparison of diurnally constant and fluctuating light. J Plankton Res 4:705-724

Craig H (1953) The geochemistry of the stable carbon isotopes. Geochim Cosmochim Acta 3:53-92

Craig $H$ (1954) Carbon-13 in plants and the relationship between carbon-13 and carbon-14 variations in nature. J Geol 62:115-149

Dainty J (1963) Water relations of plant cells. In: Preston RD (ed) Advances in botanical research. Academic Press, London, p 276-326
Den Hartog C (1970) The seagrasses of the world. NorthHolland Publ, Amsterdam

Descolas-Gros C, Oriol L (1992) Variations in carboxylase activity in marne phytoplankton cultures. $\beta$-carboxylation in carbon flux studies. Mar Ecol Prog Ser 85:163-169

Doohan ME, Newcomb EH (1976) Leaf ultrastructure and $\delta^{13} \mathrm{C}$ values of three seagrasses from the great barrier reef. Aust J Plant Physiol 3:9-23

Dring MJ (1982) The biology of marne plants. Cambridge University Press, Cambridge

Duarte CM. Marbá N, Agawin N, Cebrián J, Enríquez S, Fortes MD, Gallegos ME, Merino M. Olesen B, SandJensen K, Uri J, Vermaat J (1994) Reconstruction of seagrass dynamics: age determinations and associated tools for the seagrass ecologist. Mar Ecol Prog Ser 107:195-209

Durako MJ (1993) Photosynthetic utilization of $\mathrm{CO}_{2 \mid \text { iaj }}$ and $\mathrm{HCO}_{3}$ in Thalassia testudinum (Hydrocharitaceae). Mar Biol 115:373-380

Durako MJ, Hall MO (1992) Effects of Light on the stable carbon isotope composition of the seagrass Thalassia testudinum. Mar Ecol Prog Ser 86:99-101

Durako MJ, Sackett WM (1991) Influence of the carbon source on the stable carbon isotopic composition of the seagrass Thalassia testudinum. In: Flitton S (ed) Stable isotopes in plant nutrition, soil fertility and environmental studies. International Atomic Energy Agency, Vienna, p $453-462$

Durako MJ, Sackett WM (1993) Effects of $\mathrm{CO}_{2}(\mathrm{aq})$ on the carbon 1 sotopic composition of the seagrass Thalassia testudınum Banks ex König (Hydrocharitaceae). J Exp Mar Biol Ecol 169:167-180

Ehleringer JR, Osmond CB (1989) Stable isotopes. In: Pearcy RW, Ehleringer JR, Mooney HA, Rundel PW (eds) Plant physiological ecology. Chapman \& Hall, London, $p$ $281-300$

Enoch HZ, Olesen JM (1993) Plant response to irrigation with water enriched with carbon dioxide. New Phytol 125 $249-258$

Farquhar GD, Ehleringer JR, Hubick KT (1989) Carbon isotope discrimination and photosynthesis. Ann Rev Plant Physiol Plant Mol Biol 40:503-537

Farquhar G.D. O'Leary MH, Berry JA (1982) On the relationshup between carbon isotope discrimination and the intercellular carbon dioxide concentration in leaves. Aust $\mathrm{J}$ Plant Physiol 9:121-137

Fischer G, Wiencke C (1989) Stable carbon isotopes in organic matter from benthic marne macroalgae (Antarctica): evidence of light intensity etfects. J Mar Biol Ass UK 69:7321

Fleming M, Lin G, Sternberg L (1990) Influence of mangrove detritus in an estuarine ecosystem. Bull Mar Sci 47 : 663669

France RL (1995) Carbon-13 enrichment in benthıc compared to planktonic algae: foodweb implications. Mar Ecol Prog Ser 124:307-312

Fry B (1977) Stable carbon isotope ratios: a tool for tracing food channs. MA thesis, Unversity of Texas, Austin

Fry $B(1984){ }^{13} \mathrm{C} /{ }^{12} \mathrm{C}$ ratios and the trophic importance of algae in Florida Syringodium filiforme seagrass meadows. Mar Biol 79:11-19

Fry B, Lutes R, Northam M, Parker PL, Ogden, J (1982) A ${ }^{1.3} \mathrm{C} /{ }^{12} \mathrm{C}$ comparison of food webs in Caribbean seagrass meadows and coral reefs. Aquat Bot 14:389-398

Fry B, Parker PL (1979) Animal diet in Texas seagrass meadows: $\delta^{13} \mathrm{C}$ evidence for the importance of benthic plants Estuar Coast Mar Sci 8:499-509

Fry B, Scalan RS, Parker PL $(1983){ }^{13} \mathrm{C} /{ }^{12} \mathrm{C}$ ratios in marine 
food webs of the Torres Strait, Queensland. Aust J Mar Freshwater Res 34:707-715

Grice AM, Loneragan NR, Dennison WC (1996) Light intensity and the interactions between physiology, morphology and stable isotope ratios in five species of seagrass. J Exp Mar Biol Ecol 195:91-110

Guy RD, Fogel MF, Berry, JA, Hoering TC (1987) Isotope fractionation during oxygen production and consumption by plants. In: Biggins J (ed) Progress in photosynthetic research III. Martinus Nijhoff, Dordrecht, p 597-600

Guy RD, Vanderberghe GC, Turpin DH (1989) Significance of phosphoenolpyruvate carboxylase during ammonium assimilation. Plant Physiol 89:1150-1157

Haines EB (1976a) Stable carbon isotope ratios in the biota, soils and tidal water of a Georgia salt marsh. Estuar Coast Mar Sci 4:609-616

Haines EB (1976b) Relation between stable isotope composition of fiddler crabs, plants and soils in a salt marsh. Limlnol Oceanogr 21:880-883

Harlin MM, Thorne-Miller B, Boothroyd JC (1982) Seagrasssediment dynamics of a flood-tidal delta in Rhode Island (U.S.A.). Aquat Bot 14:127-138

Harrigan P, Zieman JC, Macko SA (1989) The base of nutritional support for the gray snapper (Lutjanus griseus): an evaluation based on a combined stomach content and stable isotope analysis. Bull Mar Sci 44:65-77

Heck Jr KL, Able KW, Roman CT, Fahay MP (1995) Composition, abundance, biomass, and production of macrofauna in a New England estuary: comparisons among eelgrass meadows and other nursery habitats. Estuaries 18: $379-389$

Hemminga MA, Huiskes AHL, Steegstra M, van Soelen $J$ (1996) Assessment of carbon allocation and biomass production in a natural stand of the salt marsh plant Spartina anglica using ${ }^{13} \mathrm{C}$. Mar Ecol Prog Ser 130:169-178

Hemminga MA, Nieuwenhuize J (1990) Seagrass wrackinduced dune formation on a tropical coast (Banc d'Arguin, Mauritania). Estuar Coast Shelf Sci 31:499-502

Hemminga MA, Slim FJ, Kazungu J, Ganssen GM, Nieuwenhuize J, Kruyt NM (1994) Carbon outwelling from a mangrove forest with adjacent beds and coral reefs (Gazi Bay, Kenya). Mar Ecol Prog Ser 106:291-301

Howard RK, Edgar GJ, Hutchings PA (1989) Faunal assemblages of seagrass beds. In: Larkum AWD, McComb AJ, Shepherd SA (eds) Biology of seagrasses. Elsevier, Amsterdam, p 536-564

IUPAC (1994) Atomic weights of the elements 1993. Pure Appl Chem 66:2423-2444

Keeley JE, Osmond CB, Raven JA (1984) Stylites, a vascular land plant without stomata absorbs $\mathrm{CO}_{2}$ via its roots Nature 310:694-695

Keeley JE, Sandquist DR (1992) Carbon: freshwater plants. Plant Cell Environ 15:1021-1035

Kroopnick PM (1985) The distribution of ${ }^{13} \mathrm{C}$ of $\mathrm{\Sigma CO}_{2}$ in the world oceans. Deep Sea Res 32(1):57-84

Kübler JE, Raven JA (1994) Consequences of light limitation for carbon acquisition in three rhodophytes. Mar Ecol Prog Ser 110:203-209

Kübler JE, Raven JA (1995) The interaction between inorganic carbon acquisition and light supply in Palmaria palmata (Rhodophyta). J Phycol 31:369-375

Kuo J, McComb AJ (1989) Seagrass taxonomy, structure and development. In: Larkum AWD. McComb AJ, Shepherd SA (eds) Biology of seagrasses. Elsevier, Amsterdam, p $6-73$

Lajtha K, Marshall JD (1994) Sources of variation in the stable isotopic composition of plants. In: Lajtha $K$, Michener RH (eds) Stable isotopes in ecology and environmental science Blackwell, London, p 1-21

Larkum AWD, Roberts G, Kuo J, Strother S (1989b) Gaseous movements in seagrasses. In: Larkum AWD, McComb AJ, Shepherd SA (eds) Biology of seagrasses. Elsevier, Amsterdam, p 686-722

Leuschner C. Rees $\mathrm{U}$ (1993) $\mathrm{CO}_{2}$ gas exchange of two intertidal seagrass species, Zostera marina L. and Zostera noltii Hornem., during emersion. Aquat Bot 45:53-62

Limnology \& Oceanography (1995). New manuscript guidelines for the reporting of stable hydrogen, carbon, and oxygen isotope-ratio data. Limnol Oceanogr $40(6): 1182$

Lin G, Banks T, Sternberg L (1991) Variations in $\delta^{1.3} \mathrm{C}$ values for the seagrass Thalassia testudinum and its relations to mangrove carbon. Aquat Bot 40:333-341

Maberly SC, Raven JA, Johnston AM (1992) Discrimination between ${ }^{12} \mathrm{C}$ and ${ }^{13} \mathrm{C}$ by marine plants. Oecologia 91 $481-492$

Mateo N1A, Romero J, Pérez Littler M, Littler, D (1996) Dynamics of millenary organic deposits resulting from the growth of the Mediterranean seagrass Posidonia oceanica. Estuar Coast Shelf Sci (in press)

McConnaughey T, McRoy CP $(1979){ }^{13} \mathrm{C}$ label identifies eelgrass (Zostera marina) carbon in an Alaskan estuarine food web. Mar Biol 53:263-269

McMillan C, Parker PL, Fry B $(1980){ }^{13} \mathrm{C} /{ }^{12} \mathrm{C}$ ratios in seagrasses. Aquat Bot 9:237-249

Millhouse J, Strother S (1986) The effect of pH on the inorganic carbon source for photosynthesis in the seagrass Zostera muelleri Irmisch ex Aschers. Aquat Bot 24: 199-209

Mook WG, Bommerson JC, Staverman WH (1974) Carbon isotope fractionation between dissolved bicarbonate and gaseous carbon dioxide. Earth Planet Sci Lett 22:169-176

Mordacq L, Mousseau M, Deleens E (1986) A ${ }^{13} \mathrm{C}$ method of estimation of carbon allocation to roots in a young chestnut coppice. Plant Cell Environ 9:735-739

Mousseau L, Dauchez S, Legendre L, Fortier L (1995) Photosynthetic carbon uptake by marine phytoplankton: comparison of stable $\left({ }^{13} \mathrm{C}\right)$ and radioactive $\left({ }^{14} \mathrm{C}\right)$ isotope methods. J Plankton Res 17:1449-1460

O'Leary MH, Rerfe JE, Slater JD (1981) Kinetic and isotope effect studies of maize phosphoenolpyruvate carboxylase. Biochemistry 20:7308-7314

Parker PL (1964) The biogeochemistry of the stable isotopes of carbon in a marine bay. Geochim Cosmochim Acta 28 $1155-1164$

Parker PL (1976) Stable carbon isotope ratios of food webs and biogeochemical cycles in seagrass systems. Progress Report to the International Decade of Ocean Exploration: Seagrass Two Progress Report, Seagrass Ecosystem Study, Washington, DC, p 43-49

Pedersen O, Sand-Jensen K (1993) Water transport in submerged macrophyles. Aquat Bot 44:385-406

Pergent-Martini C, Pergent G (1994) Lepidochronological analysis in the Mediterranean seagrass Posidonia oceanica: state-of-the-art and future developments. Oceanol Acta 17:673-681

Peterson BJ, Fry B (1987) Stable isotopes in ecosystem studies. Ann Rev Ecol Syst 18:293-320

Peterson BJ, Howarth RW (1987) Sulfur, carbon, and nitrogen isotopes used to trace organic matter flow in the saltmarsh estuaries of Sapelo Island, Georgia. Limnol Oceanogr 35:1195-1213

Prins HBA, Elzenga JTM (1989) Bicarbonate utilization: function and mechanism. Aquat Bot 34:59-83

Rao RG, Woitchik AF, Goeyens L, Van Riet A, Kazungu J, 
Dehairs F (1994) Carbon, nitrogen contents and stable carbon isotope abundance in mangrove leaves from an East African coastal lagoon (Kenya). Aquat Bot 47:175-183

Rau GH, Takahashi T, Des Marais DJ (1989) Latitudinal variations in plankton $\delta^{13} \mathrm{C}$ : implications for $\mathrm{CO}_{2}$ and productivity in past oceans. Nature 341:516-518

Raven JA (1992) Present and potential uses of the natural abundance of stable isotopes in plant science, with illustrations from the marine environment. Plant Cell Environ 1.5:1083-1091

Raven JA, Johnston AM (1991) Mechanisms of Inorganic-carbon acquisition in marine phytoplankton and their implications for the use of other resources. Limno] Oceanogr 36 : $1701-1714$

Raven JA, Johnston AM, MacFarlane JJ (1990) Carbon metabolism. In: Cole KM, Sheath RG (eds) The biology of the red algae. Cambridge University Press, New York, p 171-202

Raven JA, Lucas WJ (1985) Energy costs of carbon acquisition In: Lucas WJ, Berry JA (eds) Inorganxc carbon uptake by aquatic photosynthetic organisms. Am Soc Plant Physiol, Rockville, MD, p 305-325

Raven JA, Walker DI, Johnston AM, Handley LL, Kübler JE (1995) Implications of ${ }^{13} \mathrm{C}$ natural abundance measurements for photosynthetic performance by marine macrophytes in their natural environment. Mar Ecol Prog Ser 123:193-205

Rezende CE, Lacerda LD, Ovalle ARC, Silva CAR, Martinelli LA (1990) Nature of POC transport in a mangrove ecosystem: a carbon stable 1sotopic study. Estuar Coast Shelf Sci 30:64.1-645

Richardson K, Griftiths H, Reed ML, Raven JA, Griffiths NM (1984) Inorganic carbon assimilation in the isoetids, Isoetes lacustris L. and Lobelia dortmanna L. Oecologia 61:115-121

Rodelli MR, Goaring JN, Gearing PJ, Marshall N, Sasekumar A (1984) Stable isotope ratio as a tracer of mangrove carbon in Malaysian ecosystems. Oecologia 61.326-333

Roeske CA, O'Leary MH (1984) Carbon isotope effects on the enzyme-catalyzed carboxylation of ribulose biphosphate. Biochemisty 23:6275-6284

Romero J, Prirez M, Mateo MA, Sala E (1994) The belowground organs of the Mediterranean sedgrass Posidonia oceanica as a biogeochemical sink. Aquat Bot 47:13-19

Sand-Jensen K, Gordon DM (1984) Differential ability of marne and freshwater macrophytes to utilize $\mathrm{HCO}_{3}^{-}$and $\mathrm{CO}_{2}$. Mar Biol 80:247-253

Sand-Jensen K, Gordon DM (1986) Variable $\mathrm{HCO}_{3}^{-}$affinity of Elodea canadiensis Micheaux in response to different $\mathrm{HCO}_{3}^{-}$and $\mathrm{CO}_{2}$ concentrations during growth. Oecologia $70: 426-432$

Sand-Jensen K, Pedersen MF, Nielsen SL (1992) Photosynthetic use of inorgamic carbon among primary and secondary plants in streams. Freshwater Biol 27:283-293

Sand-Jensen K. Revsbech NP, Jorgensen BB (1985) Microprofiles of oxygen in epiphyte communities on submerged macrophytes. Mar Biol 89:55-62

Scoffin TP (1970) The trapping and binding of subtidal carbonate sediments by marine vegetation in Bimini Lagoon, Bahamas. J Sediment Petrol 40:249-273

Sharkey TD, Berry JA (1985) Carbon isotope fractionation of algae as influenced by an inducible $\mathrm{CO}_{2}$ concentrating mechanism In: Lucas WJ, Berry JA (eds) Inoorganic carbon uptake by aquatic photosynthetic organisms. Am Soc Plant Physiol, Rockville, MD, p 389-401

Simenstad CA, Wissmar RC $(1985) \delta^{13} \mathrm{C}$ evidence of the origins and fates of organic carbon in estuarine and nearshore food webs. Mar Ecol Proy Ser 22:141-i52
Slawyk G, Minas M, Collos Y, Legendre L, Roy S (1984) Comparison of radioactive and stable isotope tracer techniques for measuring photosynthesis: ${ }^{13} \mathrm{C}$ and ${ }^{14} \mathrm{C}$ uptake by marine phytoplankton. J Plankton Res 6:249-257

Smith BN, Epstein S (1971) Two categories of ${ }^{13} \mathrm{C} /{ }^{12} \mathrm{C}$ ratios for higher plants. Plant Physiol 47:380-384

Smith BN, Oliver J, McMillan C (1976) Influence of carbon source, oxygen concentration, light intensity, and temperature on ${ }^{13} \mathrm{C} /{ }^{12} \mathrm{C}$ ratios in plant tissues. Bot Gaz $137: 99-104$

Smith FA, Walker NA (1980) Photosynthesis by aquatic plants: effects of unstirred layers in relation to assimilation of $\mathrm{CO}_{2}$ and $\mathrm{HCO}_{3}^{-}$and to carbon isotopic discrimination. New Phytol 86:245-259

Stephenson LR. Tan FC, Mann KH (1984) Stable rarbon. isotope variability in marine macrophytes and its implications for food web studies. Mar Biol 81:223-230

Stephenson LR, Tan FC, Mann KH (1986) Use of stable carbon isotope ratios to compare plant material and potential consumers in a seagrass bed and a kelp bed in Nova Scotia. Canada. Mar Ecol Prog Ser 30:1-7

Sternberg LSL, DeNiro MJ, McJunkin D, Berger R, Keeley JE (1985) Carbon, oxygen and hydrogen isotope abundances in Stylites reflect its unique physiology. Oecologia 67:598-600

Surif MB, Raven JA (1.990) Photosynthetic gas exchange under emersed conditions in eulittoral and normally submersed members of the Fucales and the Laminariales: interpretation in relation to $\mathrm{C}$ isotope and $\mathrm{N}$ and water use efficiency. Oecologia 82:68-80

Svejcar TJ, Boutton TW, Trent JD (1990) Assessment of carbon allocation with stable carbon isotope labeling. Agron J 82:18-21

Thayer GW, Parker PL, Croix MWL, Fry B (1978) The stable carbon isotope ratio of some components of an eelgrass, Zostera marina, bed. Oecologia 35:1-12

Thompson PA, Calvert SE (1994) Carbon-isotope fractionation by a marine diatom: the influence of irradiance, daylength, $\mathrm{pH}$ and nitrogen source. Limnol Oceanogr 39 . $1835-1844$

Thompson PA, Calvert SE (1995) Carbon isotope fractionation by Emiliania huxleyz. Limnol Oceanogr 40:673-679

Tomlinson PB (1.974) Vegetative morphology and meristem dependence. The foundation of productivity in seagrasses. Aquaculture 4:107-130

Wefer G, Killingley JS (1986) Carbon isotopes in organic matter from a benthic alga Halimeda incrassata (Bermuda) effects of light intensity. Chem Geol (Isotope Geosciences Section) 59:321-326

Wetzel RG, Penhale PA (1979) Transport of carbon and excretion of dissolved organic carbon by leaves and roots/rhizomes in seagrasses and thelr epiphytes. Aquat Bot 6: $149-158$

Wheeler WN (1980) Effect of boundary layer transport on the fixation of carbon by the giant kelp Macrocystıs pyrifera. Mar Biol 56:103-110

Wiencke C, Fischer G (1990) Growth and stable carbon isotope composition of cold-water macroalgae in relation to light and temperature. Mar Ecol Prog Ser 65:283-292

Yamamuro M Kayanne H. Minagawa M (1995) Carbon and nitrogen stable isotopes of primary producers in coral reef ecosystems. Limnol Oceanogr 40:617-621

Zhang JA, Quay PD, Wilber DO (1995) Carbon isotope fractionation during gas-water exchange and dissolution. Geochim Cosmochim Acta 59:107-114

Zieman JC, Macko SA, Mills AL (1984) Role of seagrasses and mangroves in estuarine food webs: temporal and spatial changes in stable isotope composition and amino acid content during decomposition. Buli Mar Sci 35:380-392 